\title{
Plant polyphenol content, soil fertilization and agricultural management: a review
}

\author{
Daniela Heimler $^{1} \cdot$ Annalisa Romani $^{2} \cdot$ Francesca Ieri $^{2}$
}

Received: 27 September 2016 / Revised: 26 October 2016 / Accepted: 12 November 2016

(C) Springer-Verlag Berlin Heidelberg 2017

\begin{abstract}
The review deals with polyphenol content of vegetables and fruits under different experimental conditions. The effect of fertilizers, mainly nitrogen containing fertilizers, on qualitative and especially quantitative content of the polyphenols mixture, was reviewed. Soil nitrogen affects both anthocyanins and flavonoids content, and generally, a higher polyphenolic content is observed when less nitrogen fertilizer is added to the soil. Also the effect of different agricultural management (conventional, organic, biodynamic, integrate) is reviewed with respect to polyphenols. In this case, a major effect has pointed out in the case of vegetables, while agricultural practice affects in a minimal way fruits polyphenols content. The effect of different management is, however, hardly pointed out, since many environmental factors are involved and affect polyphenols biosynthetic pathway.
\end{abstract}

Keywords Flavonoids · Anthocyanins · $\mathrm{N}$-fertilization · Conventional management - Organic management .

Biodynamic management

\section{Introduction}

The great number of reviews, published in the last 20 years, substantiates the importance of polyphenols and the

Annalisa Romani

annalisa.romani@unifi.it

1 Dipartimento di Scienze delle Produzioni Agroalimentari e dell' Ambiente (DISPAA), University of Florence, P.le delle Cascine 18, 50144 Florence, Italy

2 Phytolab-DISIA, Dipartimento di Statistica, Informatica, Applicazioni “G. Parenti”, University of Florence, Viale Morgagni, 59, 50134 Florence, Italy relevance of scientific studies on this subject. Taking into account the reviews published since 2008, a general overlook on the research topics can emphasize the main current fields in which the research is presently developed. The different subjects which may be inferred are: problems in the analytical assays of polyphenols [1-5], polyphenols composition of fruits and vegetables [6-10], the fate of polyphenols in postharvest technology $[11,12]$, chemistry and biochemistry [13-16], polyphenols and food [17-21], polyphenols and health [22-28]. From this short survey which takes into account only partly the last years, the great number and variety of researches on these plants metabolites can be pointed out. There is a lack of reviews on the relations between polyphenols content, fertilization and agriculture practice, with the exception of a recent review on the possibility of differentiating organic practice by means of secondary plant metabolites in carrots [29], and the review of Stefanelli et al. [18] focused on horticulture quality under minimal nitrogen and water supply.

The aim of this review is concerned with the relationships between polyphenols content, fertilization and agricultural practice correlated to soil management.

\section{Effect of nitrogen and/or potassium fertilization}

As summed up by Nguyen and Niemeyer [30], the carbon/nitrogen balance (CNB) pathways can be taken into account when studying the effect of nitrogen fertilization on phenolic content. Phenylalanine is the rate-limiting precursor for phenylpropanoid synthesis (e.g., lignin, flavonoids and condensed tannins), and at the same time, it is an essential amino acid for protein synthesis. Plant growth is heavily dependent on protein synthesis for the manufacture of photosynthetic, biosynthetic and regulatory enzymes, as well as for structural protein, and phenolic synthesis 
competes with growth for common substrate. When environmental conditions are favorable, vegetative growth generally receives resource priority over secondary metabolism and storage. In resource-rich environments, growth processes receive allocation priority for resources, decreasing the relative availability of carbon for the support of secondary metabolism and structural reinforcement. The CNB hypothesis predicts that concentrations of carbon-based secondary metabolites (e.g., terpenes, phenolics and other compounds that have only $\mathrm{C}, \mathrm{H}$ and $\mathrm{O}$ as part of their structure) will inversely correlate with nitrogen availability. On the contrary, concentrations of nitrogen-based secondary metabolites (e.g., alkaloids, nonprotein amino acids, cyanogenic compounds, proteinase inhibitors and others having $\mathrm{N}$ as part of their structure) are predicted to be directly correlated with nitrogen availability of the plant. As pointed out by Stefanelli et al. [18], nitrogen fertilization causes a decrease in polyphenols amount in most cases. Also interactions with other inorganic fertilizers or environmental conditions have been taken into account. Low nitrogen availability during flowering of grape bloom (Vitis vinifera L.) significantly enhanced the formation of phenolics, particularly flavonol glycosides at the beginning of the berryripening period, while the $\mathrm{N}$-induced differences became smaller for all classes of phenolics at later stage of maturity [31]. In grape fruits [32] with average levels of potassium fertilization, increased nitrogen supply caused a significant decrease in the content of total polyphenols, whereas when potassium supplies were high, the treatments with a higher nitrogen level resulted in higher concentrations of these compounds. A stronger accumulation of polyphenols in the fruit of vine with no nitrogen fertilization was observed, especially during the last weeks of ripening. Leaves of apple trees (Golden delicious and Rewena) [33], sugar maple (Acer saccharum) seedlings [34], red basil, Ocimum basilicum L. [30], broccoli [35] and tomato leaves [36] exhibited a decrease in flavonoids along with nitrogen fertilization. For tomato fruits, the effect of nitrogen supply was not significant and interactions were not often observed; however, fruits harvested on plants grown with the lowest nitrogen supply tend to have the highest phenolic content [37]. Nitrogen deprivation was also able to increase flavonol accumulation in mature vegetative tissue of tomato plants [38]. In the case of artichokes, a balanced NPK fertilization involves a higher polyphenols content with respect to an excessive fertilization [39].

For tartary and normal buckwheat [40] aerial parts, no significant effect on the concentration of flavonoids between low and high levels of nitrogen could be detected. In winter grain [41], total phenolic content decreases with respect to the absence of nitrogen fertilization: When $\mathrm{N}$-fertilization is applied, increasing nitrogen amount involved increased polyphenols content.
As concerns anthocyanins content, a decrease in their content or a non-correlation along with nitrogen supply was found. Specifically in the case of berries, there was no significant interaction between sampling date and N-treatment or $\mathrm{N}$-fertilization effect on the total anthocyanins and anthocyanidin levels of bilberries (Vaccinium myrtillus) in any of the 3 years considered. A significant decrease along with $\mathrm{N}$-fertilization was observed only in the case of cyaniding-3-glucoside, while for petunidin, delphinidin, malvidin and peonidin-3-glucosides, no differences were pointed out [42]. For grapevine berries [31, 43, 44] and black chokeberry [45], anthocyanins content decreased as the amount of nitrogen was increased. For vine berries, $\mathrm{N}$ supply decreases the anthocyanin content, changes the anthocyanin composition and favors the degradation of anthocyanins in berry skin [44]. In the molecular regulation of the anthocyanins biosynthesis, both positive (MYB transcription factor) and negative (LBD proteins) are involved [43]. The low-bush blueberry anthocyanins content was examined along 2 years with a fertilization mainly based on nitrogen, phosphorous and potassium. Lime was also added to the three levels of fertilizer. In year 2005, no significant differences were pointed out with the three fertilizers with or without lime, while in the year 2004 the fertilizer with the lowest nitrogen amount in the presence of lime gave the highest anthocyanins amount [46]. Blackberries [47] exhibited the highest anthocyanins content with high nitrogen and low potassium $\left(66.4 \mathrm{~kg} \mathrm{ha}^{-1}\right)$ levels. Purple-blue potatoes showed the highest anthocyanins content with the highest nitrogen fertilization $\left(120 \mathrm{~kg} \mathrm{~N} \mathrm{ha}^{-1}\right)$ and the lack of phosphorus and potassium fertilization [48].

Table 1 reports fertilization mode, polyphenols kinds (anthocyanins and flavonoids) and analysis methods.

\section{Other inorganic fertilizer}

The simultaneous applications of nitrogen, phosphorus and potassium increased total polyphenols content of bush tea (Athrixia phylicoides) only in a peculiar N, P and K combination; in all other combinations reported, no effect on polyphenols content was pointed out [49]. With commercial fertilizer containing typical macro and micronutrients, the lowest fertilization level increased the contents of flavonols and ellagic acid in strawberry (Fragaria $\times$ ananassa Duch.) [50], while $\mathrm{P}$ and $\mathrm{K}$ fertilization had little effect on red cabbage anthocyanins, and heavy fertilization negatively affects their content [51]. The same trend was reported for total phenolic content of potatoes which tends to decrease at higher mineral fertilization $[52,53]$. Elemental agricultural sulfur was added to soil in order to increase the amount of glucosinolate compounds in Brassica rapa [54]; sulfur fertilization increased the amount of total phenols while total flavonols content was reduced by 
Table 1 Fertilization characteristics and kind of polyphenols and anthocyanins analysis

\begin{tabular}{|c|c|c|c|c|}
\hline Sample under investigation & Nitrogen fertilization & Polyphenols & Anthocyanins & References \\
\hline Apple tree leaves & $\begin{array}{l}\text { From } 3.6 \text { to } 13 \mathrm{~g} \mathrm{~N} \text { per tree and } \\
\text { year }\end{array}$ & $\begin{array}{l}\text { Separated and quantified by } \\
\text { HPLC }\end{array}$ & & 33 \\
\hline Artichoke heads & 200 and $500 \mathrm{~kg} \mathrm{~N} \mathrm{ha}^{-1}$ & $\begin{array}{l}\text { Folin-Ciocalteu and HPLC } \\
\text { analysis }\end{array}$ & & 39 \\
\hline Basil & From 0.1 to $5 \mathrm{mM} \mathrm{NH}_{4} \mathrm{NO}_{3}$ & Folin-Ciocalteu method & Spectrophotometer analysis & 30 \\
\hline Bilberry & $\begin{array}{r}\mathrm{NH}_{4} \mathrm{NO}_{3} \text { from } 12.5 \text { to } \\
50.0 \mathrm{~kg} \mathrm{ha}^{-1} \text { year }^{-1}\end{array}$ & & $\begin{array}{l}\text { Separated and quantified by } \\
\text { HPLC }\end{array}$ & 42 \\
\hline Black chokeberry & $25-30 \mathrm{~kg} \mathrm{~N} \mathrm{ha}^{-1}$ & & $\begin{array}{l}\text { TLC and spectrophotometer } \\
\text { analysis }\end{array}$ & 45 \\
\hline Blackberry & 60 and $100 \mathrm{~kg} \mathrm{~N} \mathrm{ha}^{-1}$ & Folin-Ciocalteu method & $\begin{array}{l}\text { Separated and quantified by } \\
\text { HPLC }\end{array}$ & 47 \\
\hline Blueberry & 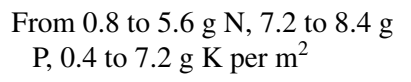 & & Spectrophotometer analysis & 46 \\
\hline Broccoli & From 105 to $225 \mathrm{~kg} \mathrm{~N} \mathrm{ha}^{-1}$ & UV absorption of leaf epidermis & & 35 \\
\hline Buckwheat aerial parts & From 0.30 to $160 \mathrm{~kg} \mathrm{~N} \mathrm{ha}^{-1}$ & $\begin{array}{l}\text { Separated and quantified by } \\
\text { HPLC }\end{array}$ & & 40 \\
\hline Bush tea & From 300 to $400 \mathrm{~kg} \mathrm{~N} \mathrm{ha}^{-1}$ & Folin-Ciocalteu method & & 48 \\
\hline Grapes & From 15 to $60 \mathrm{~kg} \mathrm{~N} \mathrm{ha}^{-1}$ & Spectrophotometer analysis & Spectrophotometer analysis & 31 \\
\hline Grapes & $\begin{array}{l}\text { From } 0 \text { to } 120 \mathrm{~kg} \mathrm{~N}^{-} \\
\quad\left(\text { as } \mathrm{NH}_{4} \mathrm{NO}\right) \mathrm{ha}^{-1}\end{array}$ & & $\begin{array}{l}\text { Separated and quantified by } \\
\text { HPLC }\end{array}$ & 43 \\
\hline Grapes & From 1.4 to $7.2 \mathrm{mM} \mathrm{N}$ & & $\begin{array}{l}\text { Spectrophotometer analysis and } \\
\text { HPLC }\end{array}$ & 44 \\
\hline Grapes & $\begin{array}{l}\text { From } 0 \text { to } 250 \mathrm{~g} \mathrm{~N} \text { per vine and } \\
\text { from } 0 \text { to } 250 \mathrm{~g} \mathrm{~K}_{2} \mathrm{O} \text { per vine }\end{array}$ & Folin-Ciocalteu & & 32 \\
\hline Potato & From 0 to $120 \mathrm{~kg} \mathrm{~N} \mathrm{ha}^{-1}$ & & $\begin{array}{l}\text { Separated and quantified by } \\
\text { UPLC }\end{array}$ & 48 \\
\hline Sugar maple leaves & $\begin{array}{l}\text { Weekly spray with } 0.02 \mathrm{M} \\
\mathrm{NH}_{4} \mathrm{NO}_{3} \text { solution }\end{array}$ & $\begin{array}{l}\text { Separated and quantified by } \\
\text { HPLC }\end{array}$ & & 34 \\
\hline Tomato & From 4 to $12 \mathrm{mM} \mathrm{NO}_{3}^{-}$solution & $\begin{array}{l}\text { Separated and quantified by } \\
\text { HPLC }\end{array}$ & & 37 \\
\hline Tomato & From 0 to $60 \mathrm{mM} \mathrm{N}$ & $\begin{array}{l}\text { Separated and quantified by } \\
\text { HPLC }\end{array}$ & & 38 \\
\hline Wheat grain & From 0 to $300 \mathrm{~kg} \mathrm{ha}^{-1}$ urea & Colorimetric and HPLC & & 41 \\
\hline
\end{tabular}

sulfur fertilization on two ecotypes; phenolic acid content was significantly increased only in the case of the Lingua di cane ecotype. In red radish (Raphanus sativus L. Mantanghon) the sulfur addition involved an increase in total phenolic and a decrease in anthocyanins contents [55].

\section{Effect of management}

The effect of management (conventional, sustainable, organic or biodynamic) is not easily predictable, and the explanation of the different behaviors is not univocal or understandable on the basis of a biochemical pathway. In the comparison of management systems, a great importance should be devoted to the different yields and the experimental growing conditions. In fact, environmental conditions affect polyphenols amount and therefore when vegetables or fruits, obtained from local market and organic farms, are compared, the results should be carefully taken into account and the differences not ascribed to the only farming method [56]. Table 2 summarizes the data of fruits polyphenols content.

As concerns apple fruits [57-59], the differences between organic and conventional management, if present, do not concern all varieties and all sampling years under study; these are of minor importance with respect to differences in sampling year and in variety.

Yellow plums [60] exhibited a lower polyphenols amount in organic with respect to conventional practice, especially concerning flavonols content. In the case of Sirah grapes, higher anthocyanins content was found in the peel of conventional managed vineyards with respect to organic ones; this result was ascribed to the extraordinary hot and dry 2002 summer climate, which caused a chemical stress of conventional production over biotic stress of 
Table 2 Fruits, analyzed tissue, growing location and results in the determination of polyphenols

\begin{tabular}{|c|c|c|c|c|}
\hline Sample & Tissue & Growing location & Results achieved & References \\
\hline Apple & Pulp mixed with skin & Neighboring organic and conventional farms & $\begin{array}{l}\text { Generally higher polyphenol content in } \\
\text { organic production }\end{array}$ & 57 \\
\hline Apple & Flesh and skin & Different farms & No differences & 58 \\
\hline Apple & $\begin{array}{l}\text { Leaves, pulp and } \\
\text { skin }\end{array}$ & Neighboring organic and integrated farms & $\begin{array}{l}\text { Higher in organic leaves and dependent on } \\
\text { cultivar in fruits }\end{array}$ & 59 \\
\hline Black currant & Fruit & Different farms in a climatically similar area & No differences & 69 \\
\hline Blueberry & Fruit & Different farms in a surrounding area & Higher in organic than in conventional & 68 \\
\hline Grapes & Skin & Neighboring parcels & Higher in conventional than in organic & 61 \\
\hline Grapes & Berry & Different farms & $\begin{array}{l}\text { No differences among organic biodynamic } \\
\text { and conventional }\end{array}$ & 62 \\
\hline Marionberry & Fruit & Same farm & $\begin{array}{l}\text { Higher in organic and sustainable than in } \\
\text { conventional production }\end{array}$ & 65 \\
\hline Orange & Fruit, edible part & Different farms & Higher in organic than in conventional & 63 \\
\hline Orange & Fruit, juice & Different farms & Higher in conventional than in organic & 64 \\
\hline Peach & Cortex and peel & Same orchard & Higher in organic than in conventional & 67 \\
\hline Strawberry & Fruit & Same farm & $\begin{array}{l}\text { Higher in organic and sustainable than con- } \\
\text { ventional production }\end{array}$ & 65 \\
\hline Strawberry & Fruit & Same pedoclimatic area & $\begin{array}{l}\text { Higher in biodynamic than in conventional } \\
\text { production }\end{array}$ & 66 \\
\hline Yellow plums & Fruit & Same farm & $\begin{array}{l}\text { Higher in conventional than in organic } \\
\text { production }\end{array}$ & 60 \\
\hline
\end{tabular}

organic production [61]. Sangiovese and Pignoletto grapes, sampled in different farms, showed no differences in the polyphenols content among conventional, organic and biodynamic practice [62]. Organic red oranges [63] exhibited higher anthocyanin and polyphenol contents with respect to integrated samples; Tunisian red oranges showed no differences in total phenolic compounds, while total flavonoids were higher in conventional juices [64].

Integrated and organic marionberry (frozen, freeze-dried, air-dried) and frozen strawberry [65] exhibited the same behavior. Fresh strawberry fruits had higher pelargonidin3-glucoside, cyaniding-3-glucoside, quercetin, kaempferol and ellagic acid contents in biodynamic with respect to conventional management. The differences were ascribed both to compost utilization in the biodynamic growing system and to the use in conventional agriculture of herbicides blocking the shikimate pathway and thus reducing the synthesis of aromatic amino acids, the starting point of the of phenolic compounds pathway [66]. Organically grown peach [67] so as organically grown blueberry [68] contained higher amounts of total polyphenols than conventionally grown fruits, while for organically grown pear [67], only two of three samples followed the same behavior; an enrichment in plant defense mechanisms against infestations, through an increase in endogenous polyphenols, could explain such behavior. The cultivation technique of black current [69] sampled in several organic and conventional farms did not affect total phenolic content.
Table 3 lists the vegetables, which were studied comparing their phenolic content under different agronomic managements. From a quick glimpse at Table 3, the large number of articles concerning tomatoes immediately comes out. Tomato polyphenols have been extensively regarded in connection with the kind of farming. A review on variations of antioxidants also in relation to the kind of cultivation [36] does not report any article on the specific issue of polyphenols variation. Total average phenolic content was slightly higher in organic agriculture in a 3-year study (1 and $7 \%$ for the two investigated cultivars) [70]. In a 2-year study, on two cultivars, no differences were pointed out [71] and on four cultivars for 3 years no differences were found apart from the behavior of one cultivar along 2 years (one case higher under organic cultivation and in the second higher under conventional cultivation) [72]. Individual phenolic compounds of the four cultivars were analyzed using HPLC-DAD-MS/MS, and 30 polyphenols were identified and quantified; the cultivation method had generally minor impact on the content of phenolic compounds with respect to growing year and cultivar. Organic tomatoes of the Redondo cultivar were richer in total phenolics and flavonoids [73]. When individual polyphenols are considered, a more complex situation is pointed out. Only rutin and naringenin contents are higher under organic management, while the content of chlorogenic acid, the most abundant component, is higher under conventional management [74]. For two cultivars along 3 years [70], quercetin 
Table 3 Vegetables, analyzed tissue, growing location and results in the determination of polyphenols

\begin{tabular}{|c|c|c|c|c|}
\hline Sample & Tissue & Growing location & Results achieved & References \\
\hline Broccoli & Florets & Same field & $\begin{array}{l}\text { No differences between organic and conven- } \\
\text { tional }\end{array}$ & 89 \\
\hline Cabbage & Internal leaves & Fields in the same location & Higher in organic than in conventional & 85 \\
\hline Carrot & Edible part & Same farm & $\begin{array}{l}\text { No differences between organic and conven- } \\
\text { tional }\end{array}$ & 87 \\
\hline Cauliflower & Edible part & Bordering fields & $\begin{array}{l}\text { No differences between organic and conven- } \\
\text { tional }\end{array}$ & 88 \\
\hline Chicory & Leaves & Plots in the same field & $\begin{array}{l}\text { No differences between biodynamic and } \\
\text { conventional }\end{array}$ & 90 \\
\hline Eggplant & Pulp & Different farms & $\begin{array}{l}\text { No differences between organic and conven- } \\
\text { tional }\end{array}$ & 81 \\
\hline Eggplant & Pulp & Neighboring farms & $\begin{array}{l}\text { Slight differences between organic and con- } \\
\text { ventional }\end{array}$ & 82 \\
\hline Lettuce & Leaves & Same field & Higher in biodynamic than in conventional & 84 \\
\hline Oat & Grains & Same farm & $\begin{array}{l}\text { No differences between organic and conven- } \\
\text { tional }\end{array}$ & 91 \\
\hline Onion & Edible part & Same farm & $\begin{array}{l}\text { No differences between organic and conven- } \\
\text { tional }\end{array}$ & 87 \\
\hline Pepper & Fruit & Fields under same conditions & $\begin{array}{l}\text { No differences between organic and conven- } \\
\text { tional }\end{array}$ & 70 \\
\hline Pepper & Green and red fruit & Different farms & $\begin{array}{l}\text { No differences between organic, integrated } \\
\text { and soilless }\end{array}$ & 80 \\
\hline Pepper & Fruit & Near fields & Higher in organic than in conventional & 78 \\
\hline Pepper & Fruit without seeds & Neighboring farms & $\begin{array}{l}\text { Total phenolics higher in organic than in } \\
\text { conventional }\end{array}$ & 79 \\
\hline Potato & Edible part & Same farm & $\begin{array}{l}\text { No differences between organic and conven- } \\
\text { tional }\end{array}$ & 87 \\
\hline Red beet & Roots & Blocks in the same experimental field & Higher in biodynamic than in conventional & 83 \\
\hline Rice & Grain & Same area & $\begin{array}{l}\text { No differences between organic and conven- } \\
\text { tional }\end{array}$ & 92 \\
\hline Spinach & Leaves & Different farms & Higher in organic than in conventional & 86 \\
\hline Tomato & Fruit & $\begin{array}{l}\text { Farms with similar environmental condi- } \\
\text { tions }\end{array}$ & $\begin{array}{l}\text { Small differences between organic and con- } \\
\text { ventional }\end{array}$ & 74 \\
\hline Tomato & Fruit & Fields under same conditions & Higher in organic than in conventional & 70 \\
\hline Tomato & Fruits without seeds & Close farms & $\begin{array}{l}\text { No differences between organic and conven- } \\
\text { tional }\end{array}$ & 71 \\
\hline Tomato & Fruit & Same farm & Dependent on year and compound & 72 \\
\hline Tomato & Fruit & Plots in the same farm & Higher in organic than in conventional & 76 \\
\hline Tomato & Fruit & Next greenhouses & $\begin{array}{l}\text { No differences between organic and conven- } \\
\text { tional }\end{array}$ & 73 \\
\hline Tomato & $\begin{array}{l}\text { Fruit, peel, pulp, } \\
\text { seeds }\end{array}$ & Two near greenhouses & Higher in organic than in conventional & 75 \\
\hline
\end{tabular}

and kaempferol amounts are higher with organic farming than with conventional one with the exception of quercetin amount in 2005 (higher in conventional farming). For cultivar Perfectpeel [75], quercetin, in the first year of cultivation, was significantly higher in the conventional product compared to the organic one, while in the second year, an inverse trend was achieved. In the second year of cultivation, naringenin and rutin were found to be higher in organic product. A long-term study (10 years) of tomatoes in organic and conventional plots showed that quercetin, naringenin and kaempferol content was higher in tomatoes from organic plots and the differences increased along with the cultivation year. These differences were ascribed to the lesser amount of available nitrogen [76].

According to Szafirowska and Elkner [77], higher content of soluble phenols and total flavonoids in organic pepper as compared to conventional one was found. Organically grown sweet pepper showed significantly higher 
content of phenolics whatever the mature stage [78], and according to authors, this increase occurs as a response both to pathogenic pressure and to a lower nitrogen availability. Total phenolic content in organic hot peppers was higher than in conventional one [79]. In other cases [70, 80], no differences were pointed out.

Only one eggplant cultivar among three and in 1 year along 2 years exhibited a higher polyphenols content under organic management [81], while no differences were found from eggplant fruits harvested in different locations under conventional and organic farming [82]. Biodynamic cultivated red beets had a higher polyphenol content than conventional and integrated ones [83] so as biodynamic lettuce leaves which exhibited a higher polyphenols content than conventional and organic ones [84]. In the case of cabbage internal leaves with four samplings from November to January, only for one sampling date, conventional grown plants exhibited a higher polyphenols content, while in the three other dates the opposite occurred [85]. Of 17 flavonoids determined, the levels of 10 were higher in organic spinach compared to conventional one [86] and total flavonoids content was significantly higher in organic spinach, with the exception of only one cultivar out of the 27 examined.

For onions, potatoes and carrots, no differences were found along 2 years and three different cultivation methods (conventional and two organic systems) [87]. Only one cauliflower genotype out of 2 and one organic cultivation out of 3 exhibited a higher polyphenols content with respect to conventional management [88]. Flavonoids and polyphenols broccoli content was unaffected by production practices [89], and no differences were found between biodynamic and conventional farming systems in the case of chicory [90]. Oat [91] and rice [92] grains exhibited no differences in the polyphenols content between organic and conventional farming.

Total phenolic and flavonoid contents in peels (zucchini squash, banana, potato, eggplant, orange, lime, mango, passion fruit and radish), leaves (zucchini squash, broccoli, carrot, collard, cassava, radish and grape), stalks (broccoli, collard and spinach) and zucchini seeds were studied. The samples were achieved from local markets, and no data are reported on their actual growing conditions. In some cases (banana peel, carrot and grape leaves), higher flavonoid contents in organic than in conventionally grown vegetables were found [93].

\section{Conclusions}

The only cases in which the increase or decrease in polyphenol content may be foreseen are bound to nitrogen supply; in most cases, a decrease in polyphenols content is correlated to a higher nitrogen supply. Nitrogen supply may derive from inorganic and/or organic soil fertilization, and the decrease is theoretically predictable based on the biochemical pathway leading to polyphenols synthesis. As concerns the kind of agricultural management, the results achieved can not be univocally explained and foreseen. Polyphenols are stress metabolites. and in this connection, many factors should be taken into account in order to explain the results and no general role actually can be drawn. The research in this peculiar field seems important in the light of the production of functional and health food. Secondary metabolites, in particular polyphenols (flavonols and anthocyanosides), present in seeds, grains, cereals, nuts, fruits, vegetables, are nutraceutical ingredients that find application in dairy products, seafood and confectionery items, in non-alcoholic beverages such as energy drinks, juices, sports drinks and in food supplements.

\section{Compliance with ethical standards}

\section{Conflict of interest None.}

Compliance with ethics requirements This article does not contain any studies with human or animal subjects.

\section{References}

1. Ignat I, Volf I, Popa VI (2011) A critical review of methods for characterization of polyphenolic compounds in fruits and vegetables. Food Chem 126:1821-1835

2. Medić-Ŝarić M, Rastija V, Bojić M (2011) Recent advances in the application of HPLC in the analysis of polyphenols in wine and propolis. J AOAC Int 94:32-42

3. Bergonzi MC, Minunni M, Bilia AR (2008) (Bio)Sensor approach in the evaluation of polyphenols in vegetal matrices. Nat Prod Commun 3:2049-2060

4. Frankel EN, Finley JW (2008) How to standardize the multiplicity of methods to evaluate natural antioxidants. J Agric Food Chem 56:4901-4908

5. Ajila CM, Brar SK, Verma M, Tyagi RD, Godbout S, Valéro JR (2011) Extraction and analysis of polyphenols: recent trends. Crit Rev Biotechnol 31:227-249

6. Haminiuk CWI, Maciel GM, Plata-Oviedo MSV, Peralta RM (2012) Phenolic compounds in fruits-an overview. Int J Food Sci Technol 47:2023-2044

7. Taamalli A, Arráez-Román D, Zarrouk M, Valverde J, SeguraCarretero A, Fernández-Gutiérrez A (2012) The occurrence and bioactivity of polyphenols in Tunisian olive products and byproducts: a review. J Food Sci 77:R83-R92

8. Xu Y, Simon JE, Welch C, Wightman JD, Ferruzzi MG, Ho L, Passinetti GM, Wu Q (2011) Survey of polyphenol constituents in grapes and grape-derived products. J Agric Food Chem 50:10586-10593

9. Soler C, Soriano JM, Mañes J (2009) Apple-products phytochemicals and processing: a review. Nat Prod Commun 4:659-670

10. Dembitsky VM, Poovarodom S, Leontowicz H, Leontowicz M, Vearasilp S, Trakhtenberg S, Gorinstein S (2011) The multiple 
nutrition properties of some exotic fruits: biological activity and active metabolites. Food Res Intern 44:1671-1701

11. Serrano M, Díaz-Mula HD, Valero D (2011) Antioxidant compounds in fruits and vegetables and changes during postharvest storage and processing. Stewart Postharvest Rev 7:1-10

12. Amarowicz R, Carle R, Dongowski G, Durazzo A, Galensa R, Kammerer D, Maiani G, Piskula MK (2009) Influence of postharvest processing and storage on the content of phenolic acids and flavonoids in foods. Mol Nutr Food Res 53:151-183

13. Tsao R (2010) Chemistry and biochemistry of dietary polyphenols. Nutrients 2:1231-1246

14. Fernandez-Panchon MS, Villano D, Troncoso AM, Garcia-Parrilla MC (2008) Antioxidant activity of phenolic compounds; from in vitro results to in vivo evidence. Crit Rev Food Sci Nutr 48:649-671

15. Wang Y, Ho C-T (2009) Polyphenols chemistry of tea and coffee: a century of progress. J Agric Food Chem 57:8109-8114

16. Cheynier V, Comte G, Davies KM, Lattanzio V, Martens S (2013) Plant phenolics: recent advances on their biosynthesis, genetics, and ecophysiology. Plant Physiol Biochem 72:1-20

17. Cheynier V (2012) Phenolic compounds: from plants to foods. Phytochem Rev 11:153-177

18. Stefanelli D, Goodwin I, Jones R (2010) Minimal nitrogen and water use in horticulture: effects on quality and content of selected nutrients. Food Res Intern 43:1833-1843

19. Callemien D, Collin S (2010) Structure, organoleptic properties, quantification methods, and stability of phenolic compounds in beer: a review. Food Res Intern 26:1-84

20. El Gharras H (2009) Polyphenols: food sources, properties and applications. a review. Int J Food Sci Technol 44:2512-2518

21. Aron PM, Shellhammer TH (2010) A discussion of polyphenols in beer physical and flavour stability. J Inst Brew 116:369-380

22. Guilford JM, Pezzuto JM (2011) Wine and health: a review. Am J Enol Vitic 62:471-486

23. Vauzour D, Rodriguez-Mateos A, Corona G, Oruna-Concha MJ, Spencer JPE (2010) Polyphenols and human health: prevention of disease and mechanism of action. Nutrients 2:1106-1131

24. Biedrzycka E, Amarowicz R (2008) Diet and health: apple polyphenols as antioxidants. Food Rev Intern 24:235-251

25. Capanoglu E, Beekwilder J, Boyacioglu D, De Vos RCH, Hall RD (2010) The effect of industrial food processing on potentially health beneficial tomato antioxidants. Crit Rev Food Sci Nutr 50:919-930

26. Stevanovic T, Diouf PN, Garcia-Perez ME (2009) Bioactive polyphenols from healthy diets and forest biomass. Curr Nutr Food Sci 5:264-295

27. Pandey KB, Rizvi SI (2009) Current understanding of dietary polyphenols and their role in health and disease. Curr Nutr Food Sci 5:249-263

28. Sajilata MG, Bajaj PR, Singhal RS (2008) Tea polyphenols as nutraceuticals. Compr Rev Food Sci Food Saf 7:229-254

29. Roose M, Kahl J, Körner K, Ploeger A (2010) Can the authenticity of organic products be proved by secondary plant substances? Biol Agric Hortic 27:129-138

30. Nguyen PM, Niemeyer ED (2008) Effects of nitrogen fertilization on the phenolic composition and antioxidant properties of basil (Ocinum basilicum L.). J Agric Food Chem 56:8685-8691

31. Keller M, Hrazdina G (1998) Interaction of nitrogen availability during bloom and light intensity during veraison. II. Effects on anthocyanin and phenolic development during grape ripening. Am J Vitic Enol 49:341-349

32. Delgado R, Martín P, del Álamo M, González M-R (2004) Changes in the phenolic composition of grape berries during ripening in relation to vineyard nitrogen and potassium fertilisation rates. J Sci Food Agric 84:623-630
33. Leser C, Treutter D (2005) Effects of nitrogen supply on growth, contents of phenolic compounds and pathogen (scab) resistance of apple trees. Physiol Plant 123:49-56

34. Sageri EPS, Hutchinson TC (2006) Responses of secondary chemicals in sugar maple (Acer saccharum) seedlings to UV-B, springtime warming and nitrogen additions. Tree Physiol 26:1351-1361

35. Fortier E, Desjardins Y, Tremblay N, Bèlec C, Côtè M (2010) Influence of irrigation and nitrogen fertilization on broccoli polyphenolics concentration. Acta Hortic 856:55-62

36. Dumas Y, Dadomo M, Di Lucca G, Grolier P (2003) Review: effect of environmental factors and agricultural techniques on antioxidant content of tomatoes. J Sci Food Agric 83:369-382

37. Bènard C, Gutier H, Bourgaud F, Grasselly D, Navez B, CarisVeyrat C, Weiss M, Gènard M (2009) Effects of low nitrogen supply on tomato (Solanum lycopersicum) fruit yield and quality with special emphasis on sugars, acids, ascorbate, carotenoids, and phenolic compounds. J Agric Food Chem 57:4112-4123

38. Stewart AJ, Chapman W, Jenkins GI, Graham I, Martin T, Crozier A (2001) The effect of nitrogen and phosphorus deficiency on flavonol accumulation in plant tissues. Plant Cell Environ 24:1189-1197

39. Lombardo S, Pandino G, Mauromicale G (2015) The nutraceutical response of two globe artichoke cultivars to contrasting NPK fertilizer regimes. Food Res Int 76:852-859

40. Christensen KB, Kaemper M, Loges R, Fretté XC, Christensen LP, Grevsen K (2010) Effect of nitrogen fertilization, harvest time, and species on the concentration of polyphenols in aerial parts and seeds of normal and tartary buckwheat (Fagopyrum sp.). Eur J Hortic Sci 75:153-164

41. Ma D, Sun D, Li Y, Wang C, Xiea Y, Guo T (2015) Effect of nitrogen fertilization and irrigation on phenolic content, phenolic acid composition, and antioxidant activity of winter wheat grain. J Sci Food Agric 95:1039-1046

42. Åkerström A, Forsum Å, Rumpunen K, Jäderlund A, Bång U (2009) Effects of sampling time and nitrogen fertilization on anthocyanidin levels in Vaccinium myrtillus fruits. J Agric Food Chem 57:3340-3345

43. Soubeyrand E, Basteau C, Hilbert G, van Leeuwen C, Delrot S, Gomès E (2014) Nitrogen supply affects anthocyanin biosynthetic and regulatory genes in grapevine cv. Cabernet-Sauvignon berries. Phytochemistry 103:38-49

44. Hilbert G, Soyer JP, Molot C, Giraudon J, Milin S, Gaudillere JP (2003) Effects of nitrogen supply on must quality and anthocyanin accumulation in berries of cv. Merlot. Vitis 42:69-76

45. Jeppsson $N$ (2000) The effects of fertilizer rate on vegetative growth, yield and fruit quality, with special respect to pigments, in black chokeberry (Aronia melanocarpa) cv. Viking. J Hortic Sci Biotechnol 83:127-137

46. Albert T, Karp K, Starast M, Moor U, Paal T (2011) Effect of fertilization on the lowbush blueberry productivity and fruit composition in peat soil. J Plant Nutr 34:1489-1496

47. Ali L, Alsanius BW, Rosberg AK, Svensson B, Nielsen T, Olsson ME (2012) Effects of nutrition strategy on the levels of nutrients and bioactive compounds in blackberries. Eur Food Res Technol 243:33-44

48. Michalskaa A, Wojdyłob A, Bogucka B (2016) The influence of nitrogen and potassium fertilisation on the content of polyphenolic compounds and antioxidant capacity of coloured potato. J Food Comp Anal 47:69-75

49. Mudau TN, Soundy P, Du Toits ES (2007) Nitrogen, phosphorus and potassium nutrition increases growth and total polyphenol concentrations of bush tea in a shaded nursery environment. HortTechnology 17:107-110

50. Anttonen MJ, Hoppula KJ, Nestby R, Verheul MJ, Karjalainen RO (2006) Influence of fertilization, mulch colour, early 
forcing, fruit order, planting date, shading, growing environment, and genotype on contents of selected phenolics in strawberry (Fragaria $\times$ ananassa Duch.) fruits. J Agric Food Chem 54:2614-2620

51. Piccaglia R, Marotti M, Baldoni G (2002) Factors influencing anthocyanin content in red cabbage (Brassica oleracea var capitata L. f rubra (L.) Thell). J Sci Food Agric 82:1504-1509

52. Hamouz K, Lachman J, Dvořák P, Jůzl M, Pivec V (2006) The effect of site conditions, variety and fertilization on the content of polyphenols in potato tubers. Plant Soil Environ 52:407-412

53. Hamouz K, Lachman J, Hejtmánková K, Pazderů K, Č́ížek M, Dvořák P (2010) Effect of natural and growing conditions on the content of phenolics in potatoes with different flesh colour. Plant Soil Environ 56:368-374

54. De Pascale S, Maggio A, Pernice R, Fogliano V, Barbieri G (2007) Sulphur fertilization may improve the nutritional value of Brassica rapa L. subsp. sylvestris. Eur J Agron 26:418-424

55. Zhou C, Zhu Y, Luo Y (2013) Effect of sulfur fertilization on the accumulation of health-promoting phytochemicals in radish sprouts. J Agric Food Chem 61:7552-7559

56. Dixon R, Paiva N (1995) Stress-induced phenylpropanoid metabolism. Plant Cell 7:1085-1097

57. Stracke BA, Rüfer CE, Weibel FP, Bub A, Watzl B (2009) Threeyear comparison of the polyphenol contents and antioxidant capacities in organically and conventionally produced apples (Malus domestica Bork. Cultivar "golden delicious"). J Agric Food Chem 57:4598-4605

58. Valavanidis A, Vlachogianni T, Psomas A, Zovoili A, Slatis V (2009) Polyphenolic profile and antioxidant activity of five apple cultivars grown under organic and conventional agricultural practices. Int J Food Sci Technol 44:1167-1175

59. Mikulic Petkovsek M, Slatnar A, Stampar F, Verberic R (2010) The influence of organic/integrated production on the content of phenolic compounds in apple leaves and fruits in four different varieties over a 2 -year period. J Sci Food Agric 90:2366-2378

60. Lombardo-Boccia G, Lucarini M, Lanzi S, Aguzzi A, Cappelloni M (2004) Nutrients and antioxidant molecules in yellow plums (Prunus domestica L.) from conventional and organic productions: a comparative study. J Agric Food Chem 52:90-94

61. Vian MA, Tomao V, Coulomb PO, Lacomb JM, Dangles O (2006) Comparison of the anthocyanin composition during ripening of Syrah grapes grown using organic or conventional agricultural practice. J Agric Food Chem 54:5230-5235

62. Tassoni A, Tango N, Ferri M (2013) Comparison of biogenic amine and polyphenol profiles of grape berries and wines obtained following conventional, organic and biodynamic agricultural and oenological practices. Food Chem 139:405-413

63. Tarozzi A, Hrelia S, Angeloni C, Morroni F, Biag P, Guardigli M, Cantelli-Forti G, Hrelia P (2006) Antioxidant effectiveness of organically and non-organically grown red oranges in cell culture systems. Eur J Nutr 45:152-158

64. Letaief H, Zemni H, Mliki A, Chebil S (2016) Composition of Citrus sinensis (L.) Osbeck cv. «Maltaise demi-sanguine» juice. A comparison between organic and conventional farming. Food Chem 194:290-295

65. Asami DK, Hong Y-J, Barrett DM, Mitchell AE (2003) Comparison of the total phenolic and ascorbic acid content of freezedried and air-dried marionberry, strawberry and corn using conventional, organic and sustainable agricultural practices. J Agric Food Chem 51:1237-1241

66. D'Evoli L, Tarozzi A, Hrelia P, Lucarini M, Cocchiola M, Gabrielli P, Franco F, Cantelli-Forti Morroni F, Lombardi-Boccia G (2010) Influence of cultivation system on bioactive molecules synthesis in strawberries: spin-off on antioxidant and antiproliferative activity. J Food Sci 75:C95-C99
67. Carbonaro M, Mattera M (2001) Polyphenoloxidase activity and polyphenol levels in organically and conventionally grown peach (Prunus persica L., cv. Regina bianca) and pear (Pyrus communis L., cv. Williams). Food Chem 72:419-424

68. Wang SY, Che C-T, Sciarappa W, Wang CY, Camp MJ (2008) Fruit quality, antioxidant capacity, and flavonoid content of organically and conventionally grown blueberries. J Agric Food Chem 56:5788-5794

69. Anttonen MJ, Karjalainen RO (2006) High-performance liquid chromatography analysis of black currant (Ribes nigrum L.) fruit phenolics grown either conventionally or organically. J Agric Food Chem 54:7530-7538

70. Chassy AW, Bui L, Renaud ENC, Van Horn M, Mitchell AE (2006) Three-year comparison of the content of antioxidant microconstituents and several quality characteristics in organic and conventionally managed tomatoes and bell peppers. J Agric Food Chem 54:8244-8252

71. Juroszek P, Lumpkin HM, Yang R-Y, Ledesma DR, Ma C-H (2009) Fruit quality and bioactive compounds with antioxidant activity of tomatoes grown on-farm: comparison of organic and conventional management systems. J Agric Food Chem 57:1188-1194

72. Anton D, Matt D, Pedastaar P, Bender I, Kazimierczak R, Roasto M, Kaart T, Luik A, Püssa T (2014) Three-year comparative study of polyphenol contents and antioxidant capacities in fruits of tomato (Lycopersicon esculentum Mill.) cultivars under organic and conventional conditions. J Agric Food Chem 62:5173-5180

73. Vinha AF, Barreira SVP, Costa ASG, Alves RC, Oliveira MBPP (2014) Organic versus conventional tomatoes: influence on physicochemical parameters, bioactive compounds and sensorial attributes. Food Chem Toxicol 67:139-144

74. Caris-Veyrat C, Amiot MJ, Tyssandier V, Grassell D, Buret M, Mikolajczak M, Guilland JC, Bouteloup-Demange C, Borel P (2004) Influence of organic versus conventional agricultural practice on the antioxidant microconstituent content of tomatoes and derived purees; consequences on antioxidant plasma status in humans. J Agric Food Chem 52:6503-6509

75. Durazzo A, Azzini E, Foddai MS, Nobili F, Garaguso I, Raguzzini A, Finotti E, Tisselli V, Del Vecchio S, Piazza C, Perenzin M, Plizzari L, Maiani G (2010) Influence of different crop management practices on the nutritional properties and benefits of tomato-Lycopersicon esculentum cv. Perfectpeel. Int J Food Sci Technol 45:2637-2644

76. Mitchell AE, Hong Y-J, Koh E, Barrett DM, Bryant DE, Ford Denison R, Kaffka S (2007) Ten-year comparison of the influence of organic and conventional crop management practices on the content of flavonoids in tomatoes. J Agric Food Chem 55:6154-6159

77. Szafirowska A, Elkner K (2009) The comparison of yielding and nutritive value of organic and conventional pepper fruits. Veg Crop Res Bull 71:111-121

78. del Amor FM, Serrano-Martínez A, Fortea I, Núñez-Delicado E (2008) Differential effect of organic cultivation on the levels of phenolics, peroxidase and capsidiol in sweet peppers. J Sci Food Agric 88:770-777

79. Kim GD, Lee YS, Cho J-Y, Lee YH, Choi KJ, Lee Y, Han T-H, Lee S-H, Park KH, Moon J-H (2010) Comparison of the content of bioactive substances and the inhibitory effects against rat plasma oxidation of conventional and organic hot peppers (Capsicum annuum L.). J Agric Food Chem 58:12300-12306

80. Marín A, Gil MI, Flores P, Hellín P, Selma MV (2008) Microbial quality and bioactive constituents of sweet peppers from sustainable production systems. J Agric Food Chem 56:11334-11341 
81. Raigón MD, Rodríguez-Burruezo A, Prohens J (2010) Effects of organic and conventional cultivation methods on composition of eggplant fruits. J Agric Food Chem 58:6833-6840

82. Luthria D, Singh AP, Wilson T, Vorsa N, Banuelos GS, Vinyard BT (2010) Influence of conventional and organic agricultural practices on the phenolic content in eggplant pulp: plant-to-plant variation. Food Chem 121:406-411

83. Bavec M, Turinek M, Grobelnik-Mlakar S, Slatnar A, Bavec F (2010) Influence of industrial and alternative farming systems on content of sugars, organic acids, total phenolic content, and the antioxidant activity of red beet (Beta vulgaris L. ssp. Vulgaris Rote Kugel). J Agric Food Chem 58:11825-11831

84. Heimler D, Vignolini P, Arfaioli P, Isolani L, Romani A (2012) Conventional, organic and biodynamic farming: differences in polyphenol content and antioxidant activity of Batavia lettuce. J Sci Food Agric 92:551-556

85. Sousa C, Valenão P, Rangel J, Lopes G, Pereira JA, Ferreres F, Seabra RM, Andrade P (2005) Influence of two fertilization regimens on the amounts of organic acids and phenolic compounds of tronchuda cabbage (Brassica oleracea L. var. costata DC). J Agric Food Chem 53:9128-9132

86. Koh E, Charoenprasert S, Mitchell AE (2012) Effect of organic and conventional cropping systems on ascorbic acid, vitamin $\mathrm{C}$, flavonoids, nitrate, and oxalate in 27 varieties of spinach (Spinacia oleracea L.). J Agric Food Chem 60:3144-3150
87. Søltoff M, Nielsen J, Holst Laursen K, Husted S, Halekoh U, Knuthsen P (2010) Effects of organic and conventional growth systems on the content of flavonoids in onions and phenolic acids in carrots and potatoes. J Agric Food Chem 58:10323-10329

88. Picchi V, Migliori C, Lo Scalzo R, Campanelli G, Ferrari V, Di Cesare LF (2012) Phytochemical content in organic and conventionally grown Italian cauliflower. Food Chem 130:501-509

89. Valverde J, Reilly K, Villacreces S, Gaffney M, Granta J, Brunton N (2015) Variation in bioactive content in broccoli (Brassica oleracea var. italica) grown under conventional and organic production systems. J Sci Food Agric 95:1163-11761

90. Heimler D, Isolani L, Vignolini P, Romani A (2009) Polyphenol content and antiradical activity of Cichorium intybus L. from biodynamic and conventional farming. Food Chem 114:765-770

91. Dimberg LH, Gissén C, Nilsson J (2005) Phenolic compounds in oat grains (Avena sativa L.) grown in conventional and organic systems. Ambio 34:331-337

92. Kesarwani A, Chiang P-Y, Chen S-S (2014) Distribution of phenolic compounds and antioxidant activities of rice kernel and their relationships with agronomic practice. Sci World J ID. doi:10.1155/2014/620171

93. Pace Pereira Lima G, da Rocha SA, Takaki M, Rodrigues Ramos PR, Orika Ono E (2008) Comparison of polyamine, phenol and flavonoid contents in plants growing under conventional and organic methods. Int J Food Sci Technol 43:1838-1843 